\title{
Status of Rose Rosette Disease as a Biological Control for Multiflora Rose
}

$\mathrm{R}$ ose rosette disease (RRD) is an eriophyid mite-transmitted disease caused by an uncharacterized etiologic agent that is lethal to multiflora rose (Rosa multiflora Thunb.). It offers promise for managing this noxious weed if certain limitations are overcome. The multiflora rose is an invasive, thorny shrub indigenous to northeastern Asia that has become prevalent in the eastern United States. Traditional control methods have included herbicides, roguing, and extended periods (5 to 6 years) of overgrazing by goats $(8,35)$. These methods have drawbacks that frequently make them impractical. An endemic pathogen, the causal agent of RRD might be managed to provide an alternative control for this woody plant. Important considerations include host range, mode of transmission, host responses, potential for damage to nontarget plants, and management tactics that will provide acceptable control of this weed.

\section{Multiflora Rose}

Multiflora rose was introduced to North America several times, mainly from Japan during the early 1800 s as an ornamental. It has been used for breeding purposes and as a rootstock for ornamental roses (28). Later, its hardiness, resistance to pests and disease, and prolific fruiting habit led it to be widely promoted as a conservation plant for cover and food for wildlife and increased soil stability. From the 1930s to the 1970s, the plant was actively promoted for conservation and as a "living fence" by a variety of state and federal agencies. Many state-operated nurseries made seedlings available at very low cost for land conservation. As a result, multiflora rose now impacts over 45 million acres of pasture, parks, recreational areas, rights-of-way,

Dr. Epstein's address is: Department of Plant Pathology, Iowa State University, Ames E-mail: aepstein@iastate.edu

Publication no. D-1998-1203-01F

(C) 1999 The American Phytopathological Society and other nontilled lands in the eastern United States (7,35).

The adaptability and weedy character of multiflora rose was noticed during the 1930 s, and by the 1940s and 1950s, several observers $(25,28,29)$ had raised questions about the advisability of its introduction. Because of the plant's fruitfulness (6) and the palatability of the fruit to various wildlife, seeds of the plant are widely dispersed, especially by fruit-eating birds such as robins (25). Browsing animals such as deer can also disseminate the seed. New plants arise by layering of the cane tips and by budding from wounded roots. The result is multicrowned, impenetrable stands that cause severe degradation of land used for grazing or recreation (Fig. 1). Multiflora rose, now widely established on nontilled land where conventional weed control measures may be difficult or expensive, has been designated a noxious weed in many states $(25,30)$.

A number of traditional methods for controlling multiflora rose are currently practiced. These include physical removal, application of herbicides, and long-term intensive grazing by goats $(8,35)$. The lands to be treated are often comparatively low in value. Chemical methods are costly and have potential for negative impacts on off-target organisms and environmental quality. Long-term, intensive grazing by goats can result in excessive soil erosion.

\section{Potential Approaches to Weed Biological Control}

Biological control of weeds has been defined as the manipulation of natural enemies (predators, parasites, and pathogens) to suppress target weeds (29). Natural enemies limit plant distribution and abundance. Plant species introduced to new areas without natural enemies often become serious weeds in their new habitat.

Three basic approaches have been proposed (29) to achieve biological weed control:

(i) The classical approach, involving introduction of "exotic" control agents obtained from the target weed's native range. This approach has been used frequently and successfully against other weed spe-

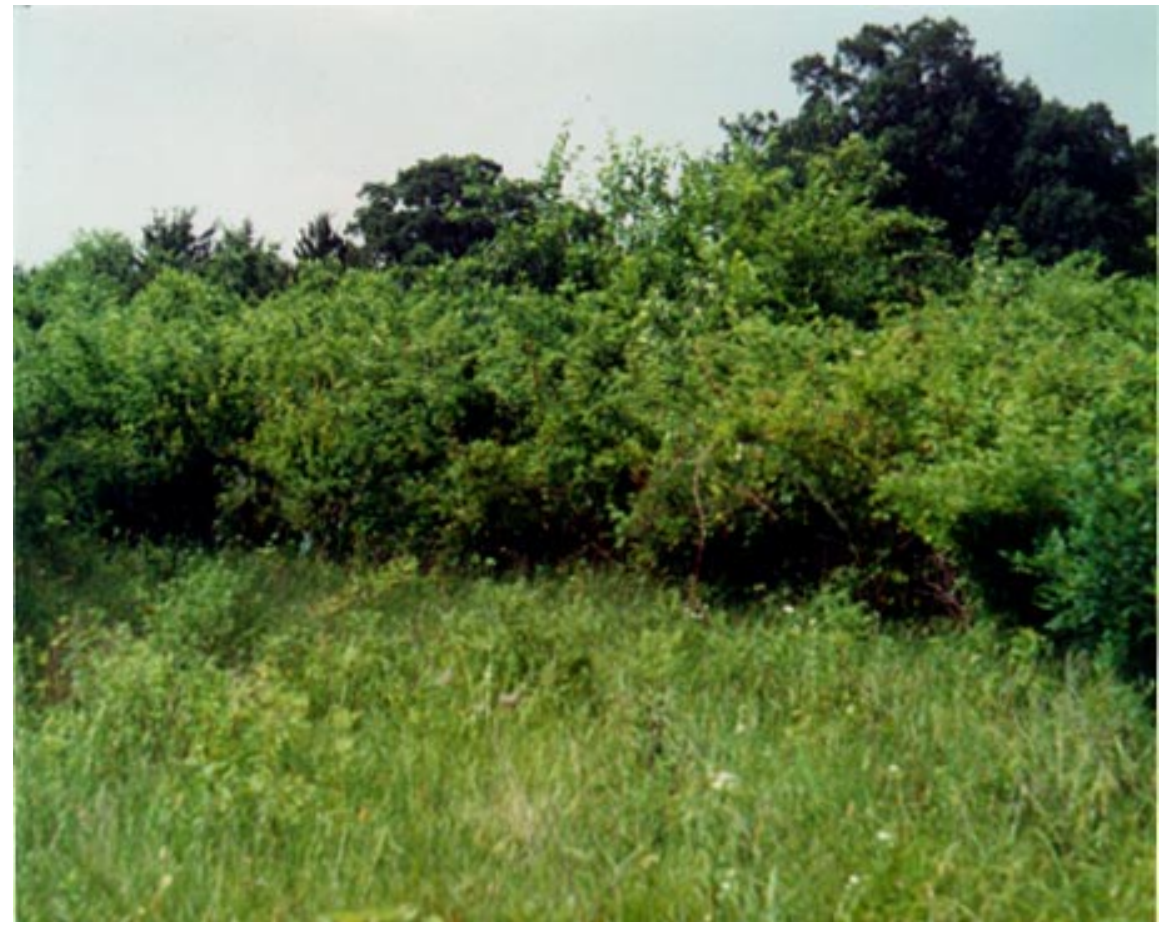

Fig. 1. An impenetrable infestation of an lowa pasture by multiflora rose that makes the land useless for grazing or recreational purposes. 
cies. However, it may entail some risk from unforeseen behavior by the exotic agent because its new habitat may lack constraints imposed by natural enemies in its native habitat (29).

(ii) The augmentation approach, based upon the inundative release of native (endemic) agents. This approach has achieved considerable success when plant pathogens have been used as agents for biological control of certain weeds $(29,33,37)$.

(iii) The conservation approach, employing manipulation of environmental and biological factors to enhance the effects of existing native or exotic biological control agents. Maintenance of suitable host plants or overwintering sites for the biocontrol agent exemplifies this approach.

Few pathogens (all fungi) have been successfully developed as biocontrol agents for weeds. No plant viruses or viruslike agents have been used in this manner. Many plant pathogens have narrow host ranges and may pose little risk of infection of nontarget plants. Exceptions can occur, and each candidate biocontrol organism should be tested thoroughly before implementation as a biocontrol agent.

The RRD, which is lethal to multiflora rose $(4,6,10,16)$, is endemic to North America $(9,21)$ and is vectored by the eriophyid mite Phyllocoptes fructiphylus (Fig. 2) (23). It has potential as an agent for biocontrol of this weed. Augmentation, using the RRD agent, should be an appropriate approach since the causal agent is endemic and appears to have a host range restricted to the genus $\operatorname{Rosa}(17,18,29)$. Use of the agent depends upon a practical and reliable method for intensifying its occurrence in the field. Also, evidence of safety to potential nontarget organisms must be demonstrated. Methods of achieving these goals appear to be (i) to directly introduce or manipulate infective vectors, or (ii) to manipulate the RRD causal agent in a manner that will result in increase of both the agent and its vector.

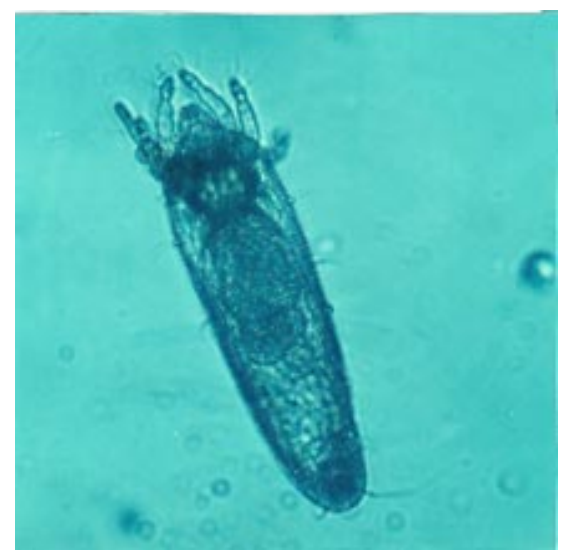

Fig. 2. Phyllocoptes fructiphylus, an eriophyid mite, is the only known vector of the rose rosette disease causal agent.

\section{RRD}

RRD, also sometimes referred to as witches'-broom, was first reported on various rose species in Manitoba, Canada, by Connors in 1940 (9). The disease is lethal to multiflora rose. It was subsequently reported from several western states and Canada by Thomas and Scott (34), from California in 1966 (36), and from Nebraska in 1968 (3).

Following these initial reports, the disease remained obscure until 1976, when Crowe observed a few symptomatic plants in Kansas and later observed disease incidence as high as $30 \%$ in hybrid rose plantings in metropolitan areas of eastern Kansas and western Missouri, and in multiflora rose hedges in adjacent rural areas (10). In one extensive hedgerow planting of $R$. multiflora, over $90 \%$ of the plants developed symptoms of RRD from 1980 to 1982. RRD is widely distributed in an area including Kansas and Nebraska on the west, Iowa, Wisconsin, Illinois, Indiana, and Ohio on the north, Arkansas, Texas, and Alabama on the south, and Pennsylvania and Maryland on the east (Fig. 3) $(4,7,10,12,14,15,19,21,35)$. RRD also occurs sporadically in several Rocky Mountain states and in California (7).

\section{Symptoms}

The symptoms of RRD are complex. The following stages of symptom progression have been described $(16,19)$.

Stage 1. The earliest symptoms include deep red to magenta coloration on the underside of leaf veins that extends into the underside of leaf blades (Fig. 4A). Shoots of affected canes are vigorous, elongate rapidly, and develop light pink (Fig. 4B) to deep magenta (Fig. 4C) coloration. Affected shoots tend to be more succulent than normal, often with noticeable proliferation of thorns, especially in cultivated roses. Affected leaves tend to be elongated, deformed, crinkled, rugose, and exhibit varying degrees of yellow and green mosaic with red pigmentation. Starch reserves are greatly reduced. Flowering is also reduced, and individual blossoms on symptomatic canes are usually distorted. Occasional plants fail to develop the intense shades of red coloration; however, these still display the other symptoms, and the disease is ultimately lethal. Temporary reversion to normal-appearing growth, resulting in canes with a mosaic of symptomatic and normal-appearing leaves, has been observed in a few plants (6). The temporary reversion results from leaves that fail to develop red pigment but remain symptomatic in terms of leaf texture and configuration (A. H. Epstein, unpublished data).

Stage 2. In the early rosette stage (Fig. 4D), leaves of infected plants display a pattern of mosaic with intense red coloration and tend to be elongated, distorted, and rugose. Many lateral buds break dormancy and start growing. Petioles are shortened, resulting in a rosette appearance of the symptomatic shoots. Exposure to freezing temperatures results in visible injury to symptomatic leaves. Growth rate of shoots on remaining nonsymptomatic portions of the plant may be greatly reduced. Flowers rarely form on canes expressing this stage of RRD.

Stage 3. In the late stage of RRD, rosetting is intense, and leaves are greatly reduced, almost hairlike and intensely red;

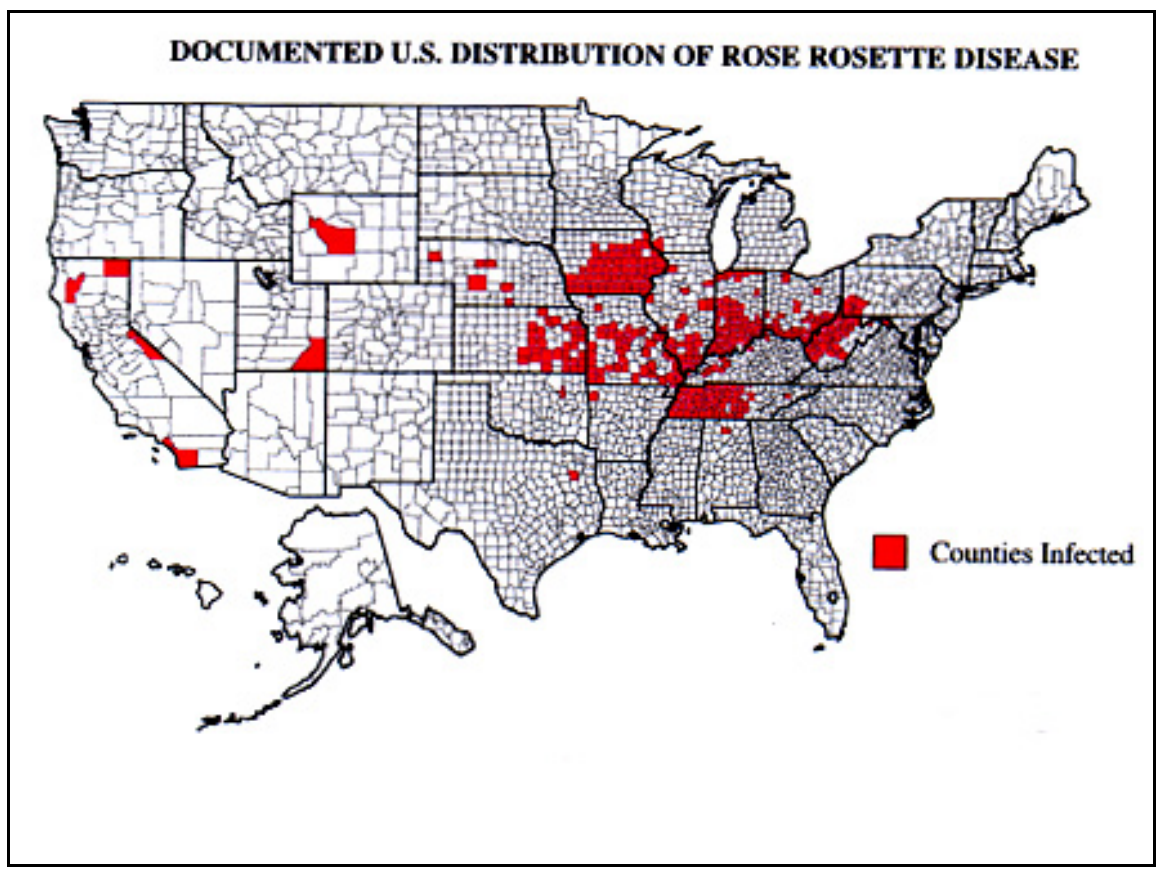

Fig. 3. Distribution of the rose rosette disease in the United States. Counties shaded in red have reported the disease. (courtesy Tim Brown, West Virginia Department of Agriculture) 

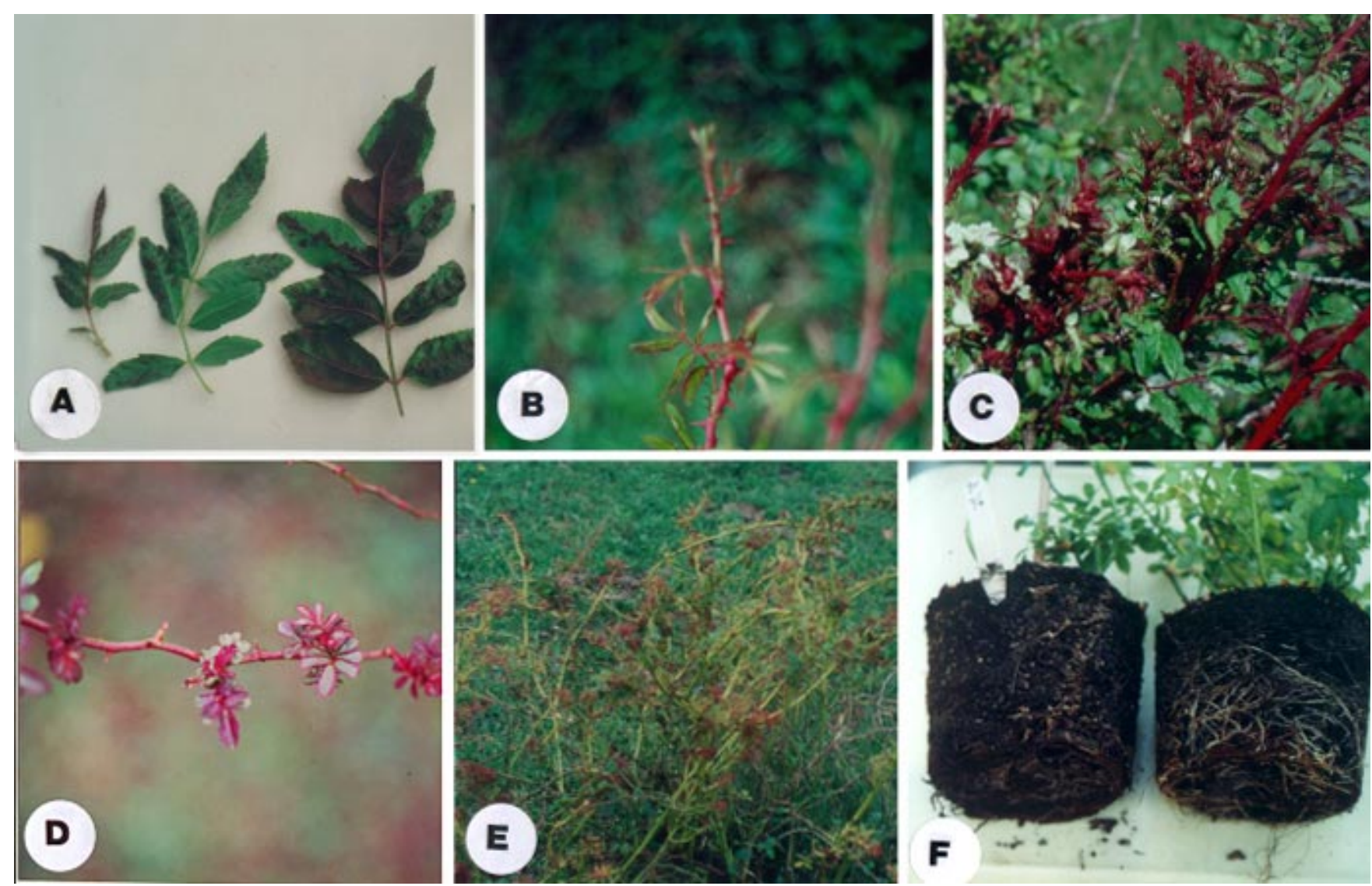

Fig. 4. Symptoms of rose rosette disease in Rosa multiflora. Infection stages are represented by panels (A to C) (stage 1), panel (D) (stage 2), and panels (E to F) (stage 3). (A) Earliest symptoms of rose rosette disease infection are characterized by deep red or magenta color development on the underside of leaf veins, often with angular patches of color on the underside of the leaf lamina. (B) Pink coloration of rapidly elongating cane apices. Leaflets are also tinged with red, tend to be elongated, become rugose in texture, and may display varying degrees of red, green, and yellow mosaic. (C) Later in the season, rapidly elongating cane apices are very succulent, deep red or magenta, and often display a proliferation of thorns. Leaflets on affected canes tend to be elongated, are rugose in texture, and display varying mosaic patterns of yellow, red, and green colored tissue. Leaf stipules are elongated. (D) Rosette formation due to leaflet distortion and shortened petioles. The rosettes develop primarily from lateral buds, which begin to grow as apical dominance is lost. Affected canes have few, if any, dormant buds. (E) Plants in stage 3 of rose rosette disease symptom development exhibit extreme distortion and dwarfing of leaflets (hair-like) and chlorotic canes bearing few viable, dormant buds. Such plants are subject to severe freezing damage and usually fail to survive the winter. (F) Formation of new rootlets is greatly reduced on plants in stage 3 symptom development (left) compared with new root formation on nonsymptomatic plants (right).
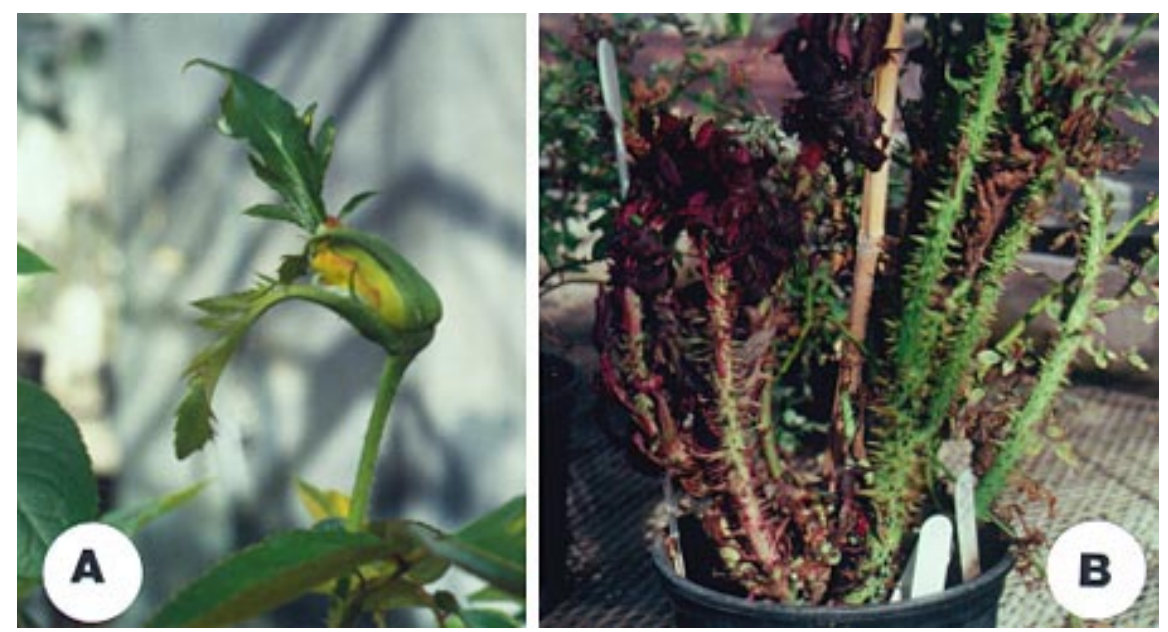

Fig. 5. Symptoms of rose rosette disease on ornamental rose cultivars are similar to those on multiflora rose. (A) Early proliferation on cv. Peace includes flower bud distortion such as seen in this figure; however, this variety does not develop red coloration of cane tips and foliage as intense as either the red-flowered varieties or multiflora rose. (B) Thorn proliferation and red coloration of swollen, vegetative canes of a red-flowered ornamental variety. petioles are very short, and most or all lateral buds break dormancy, begin to grow, and are intensely red in color. Apical growth is weak, internodes are shortened, and canes are chlorotic (Fig. 4E). Plants in advanced stages of symptom expression produce very few rootlets (Fig. 4F) and seldom survive the winter in Iowa.

Smaller plants progress through these disease stages more rapidly than larger, multicrowned plants, and infected seedlings rarely survive for longer than 1 year Single-crowned plants are usually killed by RRD in 2 to 3 years, whereas some parts of multicrowned plants may survive for as long as 4 to 5 years. Symptoms in ornamental cultivars are similar to those in multiflora rose but may include more noticeable bud distortion and more pronounced thorn proliferation (Fig. 5A and B).

\section{Host Range}

Symptoms have been reported in a number of rose species, including native roses 
such as the wood rose (Rosa woodsii), which expresses mild symptoms, and in a number of ornamental hybrid cultivars (Table 1) $(3,4,16)$. Certain native roses, $R$. setigera, $R$. arkansana, and $R$. blanda, and a wide range of rose-related species (representatives of the deciduous fruits hardy in Iowa) failed to show symptoms after graft inoculation during 2 years of observation, and the agent could not be recovered from these plants by graft inoculation to $R$. multiflora $(5,16)$. $R$. palustris and $R$. carolina, both native to the eastern United States, are resistant to infection by RRD (J. Amrine, personal communication). Thomas and Scott (34) reported that $R$. californica and $R$. spinosissima could not be infected. The weedy Macartney rose ( $R$. bracteata) is the only rose species on which the mite vectors of RRD are unable to reproduce; however, this species is susceptible to graft-transmitted RRD (J. Amrine, personal communication). A. H. Epstein (unpublished data) noted graft transmission and development of RRD symptoms on sweetbriar ( $R$. eglanteria ( $R$. rubiginosa)) from New Zealand.

$R$. multiflora transplants in host range test plots in the field (next to symptomatic plants with early-season populations of the mite vector) were symptomatic within 6 weeks after planting. Three hybrid rose plants of the hybrid cultivar Peace and one of Chrysler Imperial showed symptoms of RRD by the middle of August, and the remaining hybrid plants showed symptoms by the middle of July of the following year. No unusual symptoms were noted in any of the ambient vegetation, including the native roses. RRD seems to be restricted to the genus Rosa, and not all members of the genus are equally susceptible to infection. Peace and Chrysler Imperial roses survived longer and may be more tolerant to infection than $R$. multiflora. The rose cultivar Bonica remained symptomless in all field plantings. Although susceptible to RRD by graft transmission, this cultivar has an unusually thick cuticle that may be a barrier to mite transmission $(16,18)$. A comprehensive screening of all available ornamental rose cultivars has not been conducted.

\section{Etiology}

The causal agent of RRD has not been determined. Slykhuis (32) suggested that RRD might be a toxicogenic reaction to the feeding activity of mites rather than the result of infection by a pathogen. This is inconsistent with recent reports of graft transmission $(4,6,12,16)$. The causal agent of RRD has been speculated to be a virus, viruslike agent (11), or phytoplasma (19). There is no reaction with DAPI stain and no remission of symptoms in response to infusion treatment with tetracycline, and nothing was detected by polymerase chain reaction using primers known to detect phytoplasma $(12,16,20)$; this suggests that the causal agent is not a phytoplasma.

Large (approximately 120-nm-diameter) spherical bodies (Fig. 6) have been reported in association with the cytoplasm of symptomatic tissues $(16,24)$. These bodies, which also have been reported in tissues of several other disease agents transmitted by phytophagous mites (26), are bounded by a multi-lamellar membrane and seem to be a

Table 1. Plant species resistant or susceptible to the rose rosette disease agent of multiflora rose

\begin{tabular}{|c|c|c|c|}
\hline \multicolumn{2}{|c|}{ Susceptible } & \multicolumn{2}{|c|}{ Resistant } \\
\hline Binomial & Common name & Binomial & Common name \\
\hline Rosa woodsii & Wood rose & R. setigera & Prairie rose \\
\hline R. multiflora & Multiflora rose & R. aricularis & Prairie rose \\
\hline R. bracteata & Macartney rose & R. arkansana & Prairie rose \\
\hline \multirow{17}{*}{$\begin{array}{l}\text { R. rugosa } \times \\
\quad \text { R. odorata cvs. } \\
\text { Peace, Chrysler, } \\
\text { Imperial, Bonica } \\
\text { R. eglanteria }\end{array}$} & Hybrid Tea rose & R. blanda & Prairie rose \\
\hline & & R. palustris & \\
\hline & & R. carolina & \\
\hline & & R. californica & \\
\hline & Sweetbriar & R. spinosissima & \\
\hline & & $\begin{array}{l}\text { Malus sylvestris } \\
\text { cvs. Jonathan and } \\
\text { Wealthy }\end{array}$ & Apple \\
\hline & & $\begin{array}{l}\text { Pyrus communis } \\
\text { cv. Bartlett }\end{array}$ & Pear \\
\hline & & $\begin{array}{l}\text { Prunus armeniaca } \\
\text { cv. Goldcot }\end{array}$ & Apricot \\
\hline & & $\begin{array}{l}\text { P. cerasus } \\
\text { cv. Montmorency }\end{array}$ & Cherry \\
\hline & & $\begin{array}{l}\text { P. persica } \\
\text { cv. Hale Haven }\end{array}$ & Peach \\
\hline & & $\begin{array}{l}\text { P. domestica } \\
\text { cv. Stanley }\end{array}$ & Plum \\
\hline & & $\begin{array}{l}\text { Rubus occidentalis } \\
\text { cv. Blackhawk }\end{array}$ & Raspberry \\
\hline & & $\begin{array}{l}\text { R. idaeus } \\
\text { cv. Latham }\end{array}$ & Raspberry \\
\hline & & $\begin{array}{l}\text { R. philadelphiacus } \\
\text { cv. Darrow }\end{array}$ & Blackberry \\
\hline & & $\begin{array}{c}\text { Fragaria xananassa } \\
\text { cv. Ozark Beauty }\end{array}$ & Strawberry \\
\hline & & F. vesca & Alpine strawberry \\
\hline & & Potentilla fruticosa & Potentilla \\
\hline
\end{tabular}

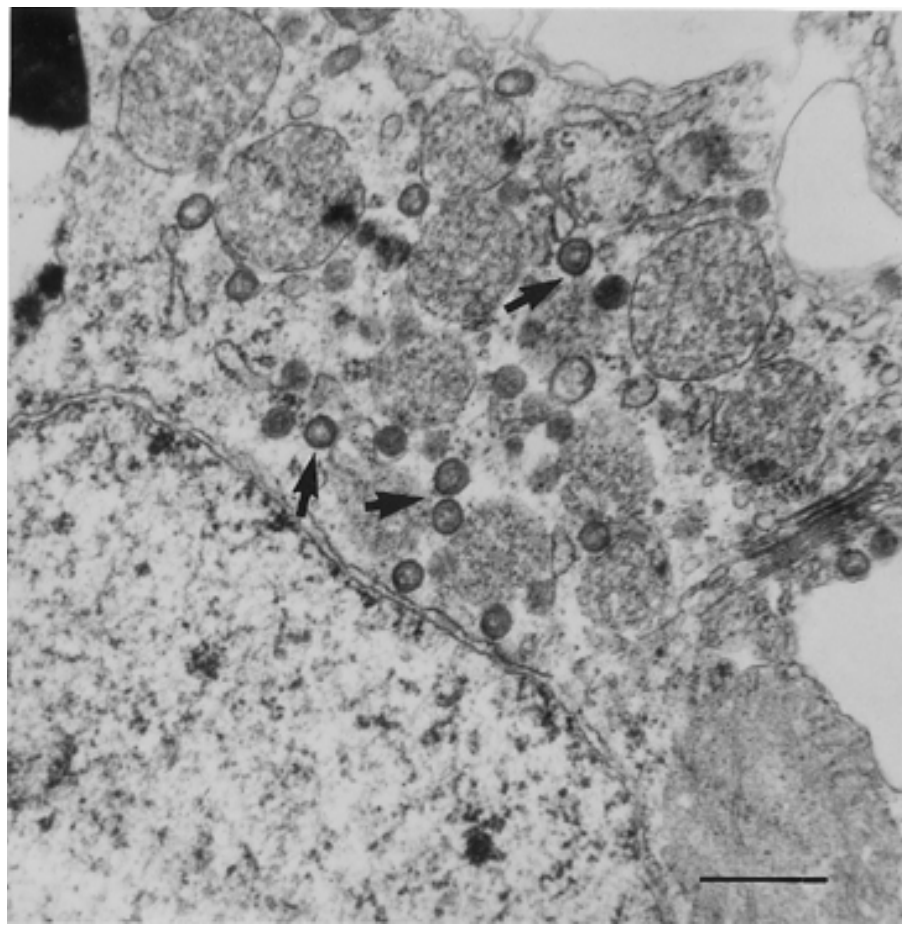

Fig. 6. Transmission electron micrograph of characteristic double-membrane bodies (arrows) in cells from symptomatic multiflora rose. Bar $=500 \mathrm{~nm}$. 
response of the diseased plant rather than the causal agent itself.

Di et al. (11) reported the presence of three double-stranded RNAs (dsRNAs) in a high proportion of plants displaying RRD symptoms. However, these dsRNAs have since been isolated from nonsymptomatic plants and are probably not related to the causal agent of RRD (20). Heat therapy applied to RRD-symptomatic plants has not resulted in symptom remission (16).

\section{Transmission}

Transmission efficiency of inoculation methods is highly variable. Doudrick (12) reported successful transmission of RRD by grafting of buds from symptomatic plants and mechanical transmission with crude sap extracted from symptomatic tissue. This method consisted of a razor blade cut made into the bud and cortical tissues through a droplet of sap from symptomatic tissue. Our attempts at mechanical transmission in the greenhouse have yielded few successes (16). None of our razor blade inoculations resulted in development of RRD symptoms. Of a total of 120 plants inoculated by means of multiple minuten stab wounds through droplets of sap from symptomatic tissue, only two subsequently developed symptoms.

No soil-mediated transmission of RRD has been detected, and seedlings derived from field-collected seed, from either diseased or healthy plants, did not develop symptoms of RRD. No root grafts between adjacent multiflora rose plants have been found (16). Attempts to transmit RRD to $R$. multiflora with dodder have been negative, regardless of the species of Cuscuta used ( $C$. campestris, $C$. gronovii, and $C$. pentagona). Although the dodder grew out over the rose, no haustorial penetration occurred (16).

The most efficient means of experimen- tal transmission of RRD is by grafting. In greenhouse tests, grafted shields lacking buds are as effective as those with buds for transmitting RRD; however, graft success in the field with budless shields is poor (Table 2) (16). Transmission efficiency is greatest when the graft is located on the apical third of rapidly growing, vegetative shoots. This is consistent with previous reports suggesting graft transmission to large, rapidly growing transplants was more efficient than to slow-growing, rooted cuttings (5). After grafting, some plants exhibit vein reddening on terminal leaflets and breaking of buds (into short, red laterals) prior to visible growth of the graft. In others, symptoms of systemic infection do not appear until the grafted bud has developed a shoot 10 to $20 \mathrm{~cm}$ in length.

In the field, a grafting technique utilizing a modified bud shield as the scion has been effective in the transmission of RRD and has been efficient for augmentation of the disease to achieve biological control of multiflora rose. Grafts made on vigorous current-season, vegetative canes (in Iowa from mid-May through mid-July) have the highest rates of establishment, with transmission of RRD approaching $80 \%$; those made on older canes (flowering) result in a low percentage of viable graft formation and transmission $(16,18)$. Graft success and RRD transmission is enhanced by removal of three to four leaves above and below the graft site and excision of the apical bud of the stock (recipient) cane. Grafts fail when exposed to freezing temperatures or drought.

\section{Vectors}

Allington et al. (3) reported transmission of RRD by the eriophyid mite, Phyllocoptes fructiphylus (23), (Fig. 2) to R. eglanteria and to $R$. multiflora using mites col-

Table 2. Percent graft transmission efficiency of rose rosette disease

\begin{tabular}{lcc}
\hline Environment $^{\mathbf{z}}$ & Budded shields & Budless shields \\
\hline Field & & \\
Current season growth & 84 & 4 \\
1-year-old canes & 9 & 0 \\
Greenhouse & 82 & 79 \\
\hline
\end{tabular}

${ }^{\mathrm{z}}$ Source and recipient were from the same environment.

Table 3. Seasonal variation in number of eriophyid mites per shoot of multiflora rose in Iowa

\begin{tabular}{lccc}
\hline Month & Healthy $^{\mathbf{y}}$ & Symptomatic & Symptomatic clump $^{\mathbf{z}}$ \\
\hline May & $0.6 \mathrm{a}$ & $0.6 \mathrm{a}$ & $5.2 \mathrm{~b}$ \\
June & $2.4 \mathrm{a}$ & $6.8 \mathrm{a}$ & $22.0 \mathrm{~b}$ \\
July & $4.2 \mathrm{a}$ & $32.6 \mathrm{~b}$ & $42.2 \mathrm{~b}$ \\
August & $4.8 \mathrm{a}$ & $100.2 \mathrm{~b}$ & $391.6 \mathrm{c}$ \\
September & $6.6 \mathrm{a}$ & $152.8 \mathrm{~b}$ & $533.8 \mathrm{c}$
\end{tabular}

y Representative data are selected from Epstein and Hill (16). Treatment means across columns followed by the same letter are not significantly different $(P \leq 0.05)$.

${ }^{\mathrm{z}}$ Symptomatic clump: a dense stand of symptomatic plants. lected from symptomatic plants. Crowe (10) reported that eriophyid mites were not consistently found on hybrid roses, and Doudrick et al. reported inconsistent transmission of RRD with mites $(12,13)$. Amrine et al. (6) have shown conclusively that the eriophyid mite $P$. fructiphylus is a vector of RRD. In the laboratory, transmission efficiency was as high as $92 \%$; low efficiency of $9 \%$ in the field may have been due to drought conditions (5). Amrine et al. have suggested that the causal agent may be semi-persistent or persistent and that the mite loses much of its capacity to transmit the agent after 10 days (5). Transmission efficiency is unknown.

Populations of $P$. fructiphylus are generally higher (by a factor as high as 17) on symptomatic $R$. multiflora than on nonsymptomatic plants (Table 3) $(5,16,18)$. Similarly, Adams and Thresh (1) reported higher populations of eriophyid mite vectors on symptomatic black currant plants infected by the black currant reversion disease than on nonsymptomatic plants.

Amrine et al. (5) and Keifer (23) believed that eriophyid mites are disseminated by wind; however, Epstein et al. (18) reported no vector mites caught in Burkhard suction traps operated in the vicinity of vector-colonized multiflora rose plants. Nothing is known about the potential efficiency for air-transported mites to act as vectors of the RRD agent. In addition, Shvanderov (31) reported phoretic movement of significant numbers of other species of eriophyid mites on the bodies of small arthropods such as aphids and thrips. Although mites were observed clinging to various transporting arthropods for up to $30 \mathrm{~min}$, transport of the mite to a suitable host was considered accidental. Epstein also observed $P$. fructiphylus occasionally associated with aphids on infected multiflora rose (unpublished data). This association is unlikely to be a means for mass population movement because of its rare

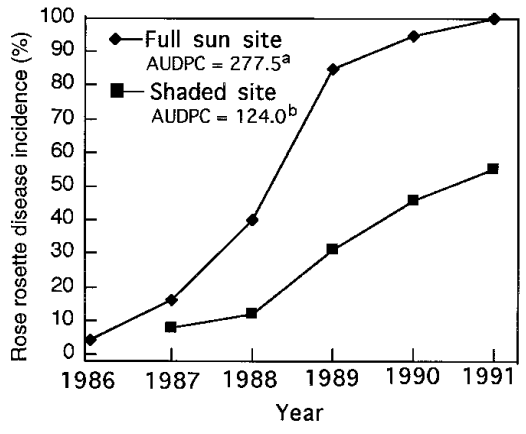

Fig. 7. Progress of rose rosette disease in a natural stand of multiflora rose from 1986 to 1991. Each point is the mean of four replications. Plots were located in full sun or in shade. Area under the disease progress curve (AUDPC) values were significantly higher in the full-sun sites than in the shaded sites $\left(\mathrm{LSD}_{0.05}=\right.$ 41.03). 
occurrence. Although the means by which the mite and the associated RRD agent are dispersed remains unclear, no other vectors have been implicated in the transmission of RRD.

\section{Epidemiology}

RRD occurs sporadically in the field in Iowa $(14,15)$. The sporadic nature of the disease may reflect the interaction of diverse edaphic factors that affect vector ability to reproduce, disperse, and overwinter. Stand density and the incidence of symptomatic plants are such factors (Table 3 ). Dense stands of infected multiflora rose plants favor rapid increase and dispersal of the vector and more rapid spread of RRD than occurs in fields with widely dispersed plants. The earliest seasonal mite colonies are found on symptomatic plants located in and close to large clumps of well-developed multiflora rose. These occur alone or associated with other shrubs, small trees, or brush piles, which seem to be the potential sites for eriophyid mites overwintering in Iowa $(14,15,18)$. Episodes of daily temperature fluctuation in excess of $17^{\circ} \mathrm{C}$, especially during the early winter months, seemed to be associated with collapse of overwintering mite populations in north central Iowa (18).

Natural spread of RRD in Iowa typically does not occur in the explosive manner reported previously (10). In most sites studied, the numbers of newly diseased plants remain static or increase slowly with infection rates that range from 0.006 to 0.018 logits day $^{-1}(14-16,18)$. In a few sites, the numbers of diseased plants increased rapidly for 2 to 3 years, and then the rate of increase subsided as the number of symptomless plants was depleted. Also, vector populations on symptomatic multiflora rose plants were generally lower on plants 4 to 5 years postinoculation than on those 1 to 3 years postinoculation. Under field conditions, rapid increase in the number of new infections occurs when symp-

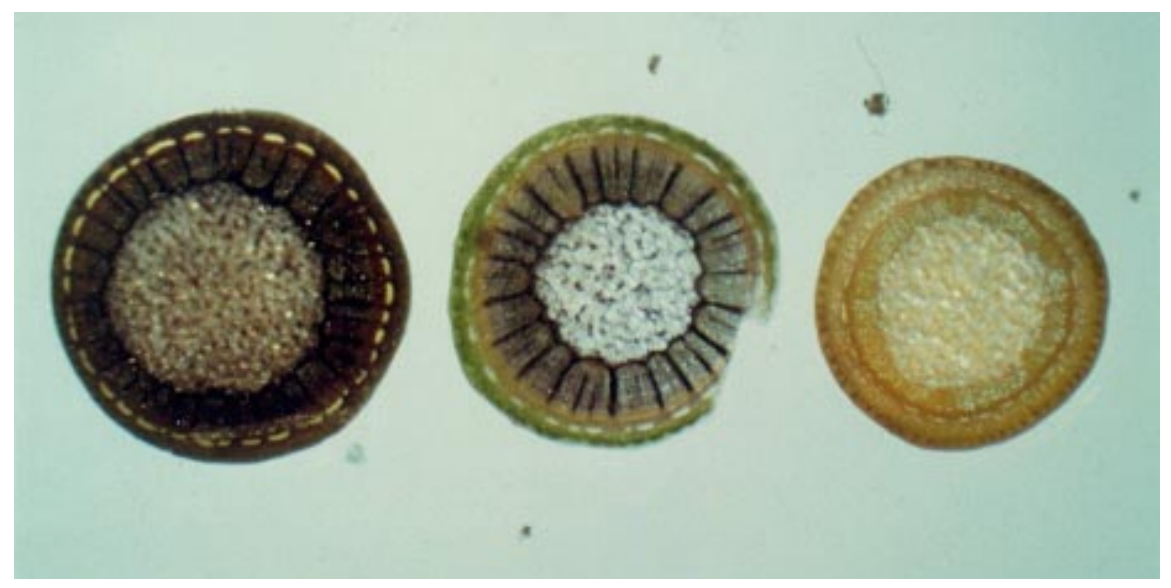

Fig. 8. Starch content of hand-cut cross sections of multiflora rose visualized by staining with potassium iodide. Stem sections are from (left) nonsymptomatic plant, (middle) symptomatic plant 6 weeks after graft inoculation, and (right) symptomatic plant expressing stage 3 symptoms. tomatic plants are located in and near sites favoring overwintering of the mite vectors. A logistic population growth model best describes progress of the disease, with higher infection rates in full sun $(\geq 8 \mathrm{~h}$ of direct sunlight per day) than in heavily shaded sites (Fig. 7) $(16,18)$.

\section{Disease Physiology and Cytology}

Multiflora rose plants graft-inoculated stored starch (Fig. 8) and reduced growth of roots and associated nonsymptomatic shoots as the symptomatic scions developed (16). Sugar content changed from predominantly sucrose $(54.8 \%)$ with lesser concentrations of fructose $(18.0 \%)$ and glucose $(27.2 \%)$ in nonsymptomatic plants to greatly reduced sucrose $(14.7 \%)$ and doubled levels of fructose $(37.4 \%)$ and glucose $(47.9 \%)$ in plants exhibiting advanced stage 1 symptoms of RRD (16). The cytoplasm of cells from tissue expressing advanced symptoms of the disease contained chloroplasts that were engorged with darkly staining material, were devoid of starch bodies, and contained deteriorating thylakoids (Fig. 9) (16). In addition, these cells contained double membranebound bodies approximately $120 \mathrm{~nm}$ in diameter. The presence of double membrane-bound bodies is characteristic of several mite-transmitted plant diseases, which have been suggested to represent a new group of plant viruses $(2,24)$. However, comparison of RRD with properties of the High Plains virus of maize and wheat (22), both of which are mite transmitted, suggests this may not be true. Cells from hosts infected with both of these diverse agents contain double membranebound bodies. Recent efforts in our laboratory have not demonstrated protein or nucleic acid patterns in extracts from RRDinfected tissues similar to those associated with the High Plains virus (22; J. Rohozinski and C. Cassavant, unpublished data). with RRD exhibited depleted levels of

\section{Biological Control Through Augmentation}

Biological control of multiflora rose was achieved by augmentation of existing RRD infection. In Iowa, pasturelands can be reclaimed from multiflora rose infestation within 5 to 6 years after augmentation. The disease agent can be transmitted by grafting buds from naturally infected plants to healthy multiflora rose. Studies at several experimental sites consistently showed that, as with natural spread, disease progress in augmented sites followed a logistic model (Fig. 10), with apparent infection rates ranging up to 0.029 logits day ${ }^{-1}$ (18). At the end of the first growing season, disease incidence did not increase, and the graft-inoculated, newly symptomatic plants (Fig. 11) were not infested with elevated mite populations. However, during the second year, the inoculated plants exhibited advanced stage 1 symptoms $(16,18)$, and over half of these were colonized by the vectors by mid-June. At the end of the third year following augmentation, approximately two-thirds of the multiflora rose plants showed new RRD infection symptoms. By the end of the fifth year, over $98 \%$ of the multiflora rose plants were
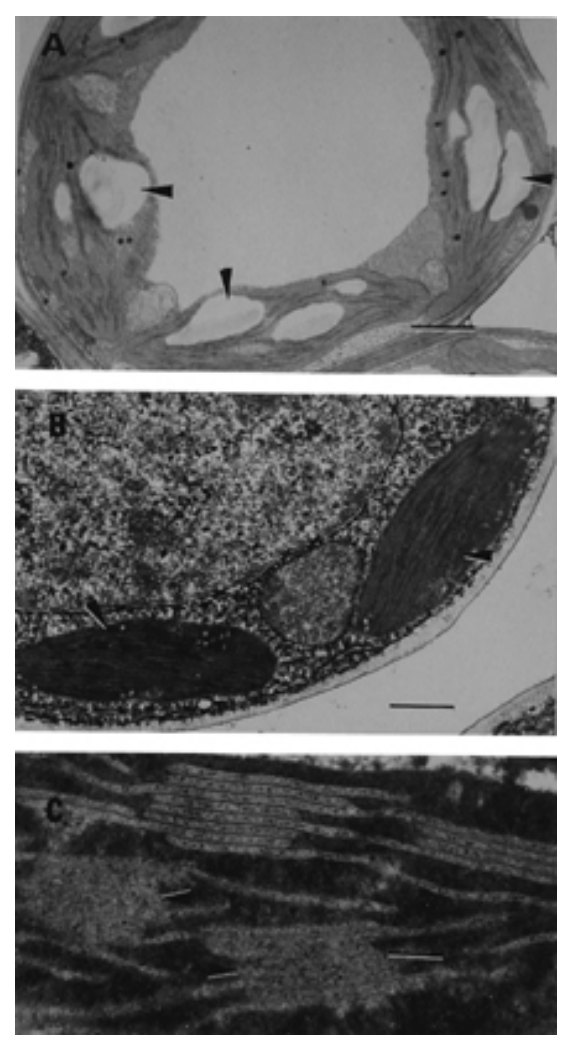

Fig. 9. Transmission electron micrograph of chloroplasts from multiflora rose. (A) Chloroplasts from nonsymptomatic plants showing numerous starch granules (arrows). Bar $=1 \mu \mathrm{m}$. (B) Chloroplasts (arrows) from symptomatic plants showing chloroplasts devoid of starch granules. Bar $=500 \mathrm{~nm}$. (C) Chloroplasts from symptomatic plants showing deterioration of grana. Bar $=100 \mathrm{~nm}$. 


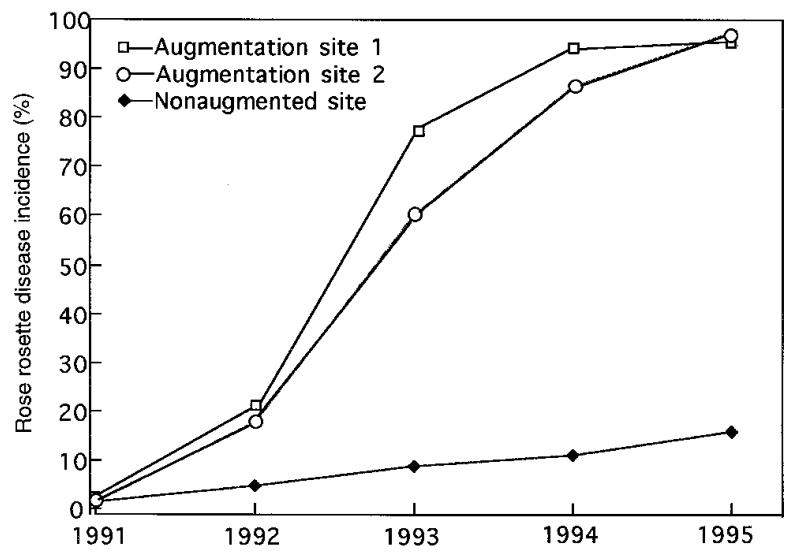

Fig. 10. Progress of rose rosette disease in two disease-augmented sites and one nonaugmented site in an lowa pasture from 1991 to 1995. Disease progress followed a logistic population growth curve model.

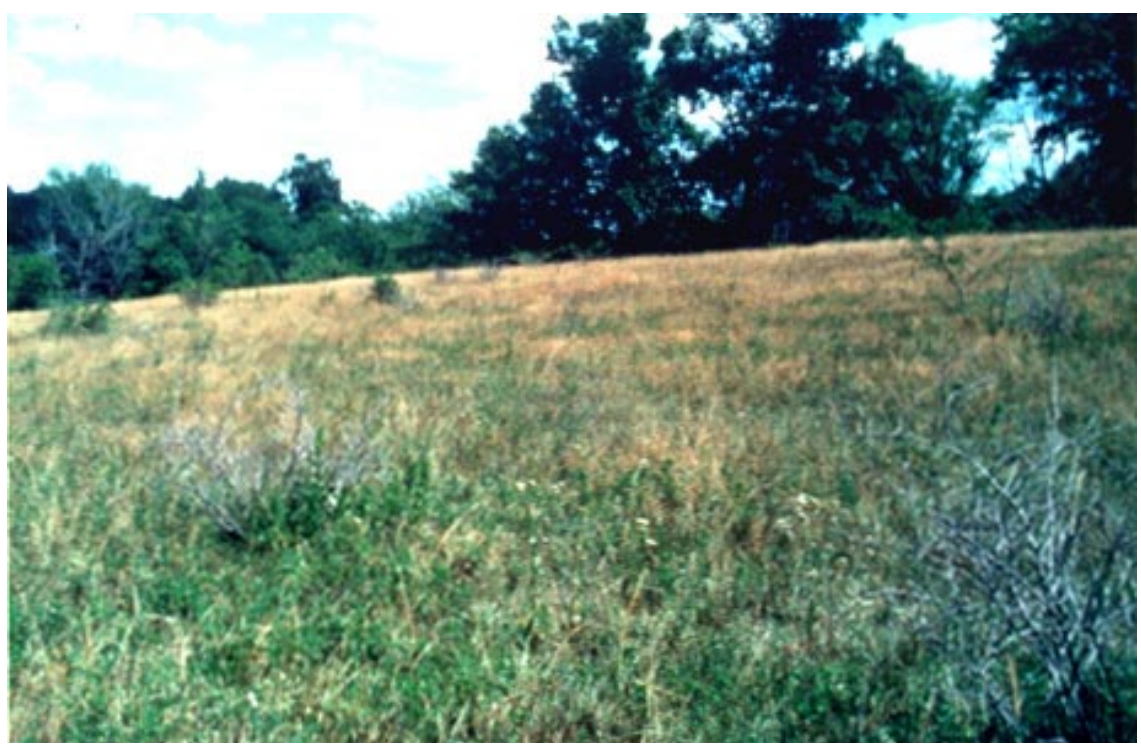

Fig. 12. An lowa pasture, with approximately $80 \%$ of the land covered by multiflora rose at the time of rose rosette disease augmentation, is virtually free of multiflora rose 6 years later. Cattle trample and remove any remaining dead bushes.

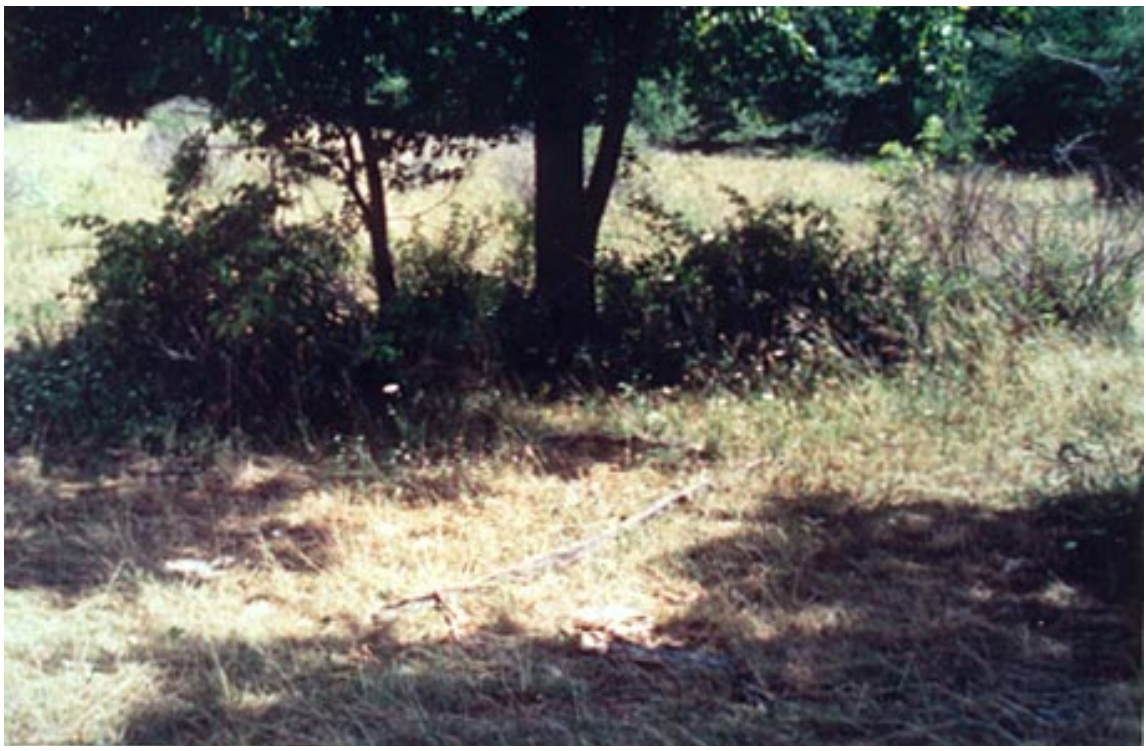

Fig. 13. Symptomless multiflora rose plants remain in tree-shaded sites adjacent to the rose rosette disease augmented site. Although not very vigorous or fruitful, these plants could serve as a source for reinfestation of the adjacent land in the future.

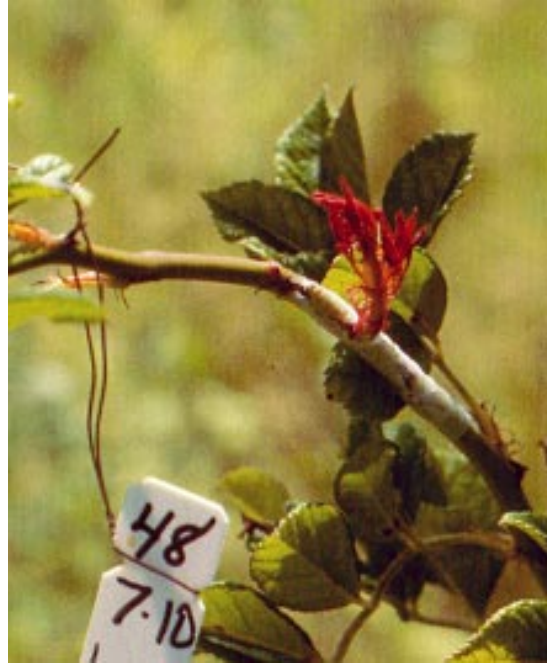

Fig. 11. Symptomatic shoot growing from the bud of a recently grafted disease scion.

infected, and all of the graft-inoculated plants, as well as those plants that became infected during the second year, were dead (Fig. 12). Spread of RRD was slower in shaded locations than in sunlit locations, and a number of symptomless plants remained in tree-shaded areas of all sites (Fig. 13). Although shaded plants were not as robust as those growing in full sun, they must be regarded as potential sources of reinfestation.

Augmentation sites interconnected by high-density disease alleys $(17,18)$ resulted in accelerated increase of the disease. As many as $96 \%$ of the ambient rose plants became symptomatic within 4 years following the augmentation inoculation. High-density disease alleys consisted of a series of inoculated plants at 1 - to $2-\mathrm{m}$ intervals interconnecting the augmentation sites (Fig. 14). Progress of the disease in north central Iowa was erratic and slow, with apparent infection rates of 0.009 logits day ${ }^{-1}$, and may have been limited by low overwintering vector populations (18). This may indicate that there is a northern limit for consistent effectiveness of RRD as a biological control for multiflora rose.

The grafting method for augmentation of RRD is low in cost, requiring a few 1.0- to 1.5-cm-wide strips of grafting tape (Parafilm) and single-edged razor blades; however, the process is labor intensive and requires 2 to $3 \mathrm{~h}$ of labor for a land area of 2 to 5 ha. Multiple augmentation sites, interconnected by high-density disease alleys, enhance the rate of movement of the vectors and disease through the stand.

Several hours of training, including familiarization with the grafting technique, identification of potential overwintering sites, and evaluation of the conduciveness of stands of multiflora rose, are required to prepare individual land managers to utilize this method of multiflora rose control Training sessions typically require 1 to $2 \mathrm{~h}$ 
of familiarization with the disease and grafting procedures (indoors). An equal amount of training time in the field is required to familiarize the student with procedures for selecting diseased budwood, identifying potential augmentation sites, and selecting receptive plants. Eight to 10 days later, an additional $2 \mathrm{~h}$ of training is recommended to check on the viability of the grafts made earlier and to replace moribund grafts.

\section{Risk of Infection in Ornamental Rose Cultivars}

The risk of RRD infection of ornamental roses as a result of augmentation is low. Disease gradients from local sources were very steep, with no spread beyond $100 \mathrm{~m}$ (Fig. 15). Symptoms did not occur in rose plants in plots located 150 to $300 \mathrm{~m}$ from the inoculum source during the first 3 years after augmentation (18). Four to 5 years after augmentation, no symptoms were observed on ornamental rose plants planted at $20-\mathrm{m}$ intervals from the inoculum source. This was coincident with a decline in vector populations on symptomatic plants 4 to 5 years after augmentation. Rates of RRD infection are very low in nonaugmented pastures. The RRD infection rates range from 5 to 10 times lower than infection rates characteristic of plant viruses in agricultural crops. In augmented pastures, RRD infection rates are approximately five times lower than rates characteristic of plant viruses $(18,27)$. Since RRD is endemic in Iowa, local augmentation increases the rate of RRD spread locally (within $100 \mathrm{~m}$ ) but does not increase the risk of long-distance spread (18). In addition, because the natural rate of infection is low, the removal of local sources of inoculum (i.e., roguing RRD-infected plants), when they occur within ornamental plantings, effectively prevents RRD epidemics in these plantings (17). Surveys conducted over a 5-year period (1992 to 1997) revealed that the annual natural RRD infection rate in ornamental rose plantings was approximately one infection per 1,200 plants. Prompt removal of these initially infected plants should prevent secondary buildup of mites and subsequent increase of RRD infections (A. H. Epstein, unpublished data).

\section{Summary}

Properly augmented, RRD is an effective agent for the biological control of multiflora rose in Iowa. After initial infection, most multiflora rose plants die within 5 to 6 years. RRD is most useful on lands with dense stands of multiflora rose. Earlyseason populations of the mite vector are found only on plants in sheltered locations such as large clumps of multiflora rose, either in pure stands or in association with other woody shrubs, small trees, and brush piles. These areas seem to be conducive to the overwintering of the mite. The rate of spread of RRD is low, and biocontrol of multiflora rose through augmentation may take longer in stands located in shaded areas or may not be effective where plants are widely dispersed and overwintering mite populations are low.

The risk of RRD infection to ornamental roses as a result of augmentation is low. The RRD infection rate in ornamental roses has been consistently lower than that in multiflora rose seedlings planted in the same plots, and RRD infection of either ornamental cultivars or multiflora rose is confined only to plants located a short distance from the augmentation sites.

Conditions for the effective use of a biocontrol agent should be based on the demonstration of biosafety and effectiveness. The RRD agent satisfies these conditions in the following way. First, no exotic or novel pathogen or vector is introduced. Instead, biocontrol is based upon augmentation of an endemic agent and its endemic vector. Second, the disease agent has a narrow host range. Potential risk to ornamental rose, an alternative host of the agent, is low. Third, although the identity of the RRD causal agent has been particularly elusive, epidemiology and management of the agent are now well established. Fourth, the RRD is lethal to multiflora rose. Appropriate management of multiflora rose through augmentation of the RRD agent will return infested lands to their original quality and productivity within 5 to 6 years without compromising environmental and water quality. Fifth, experience with field training sessions in

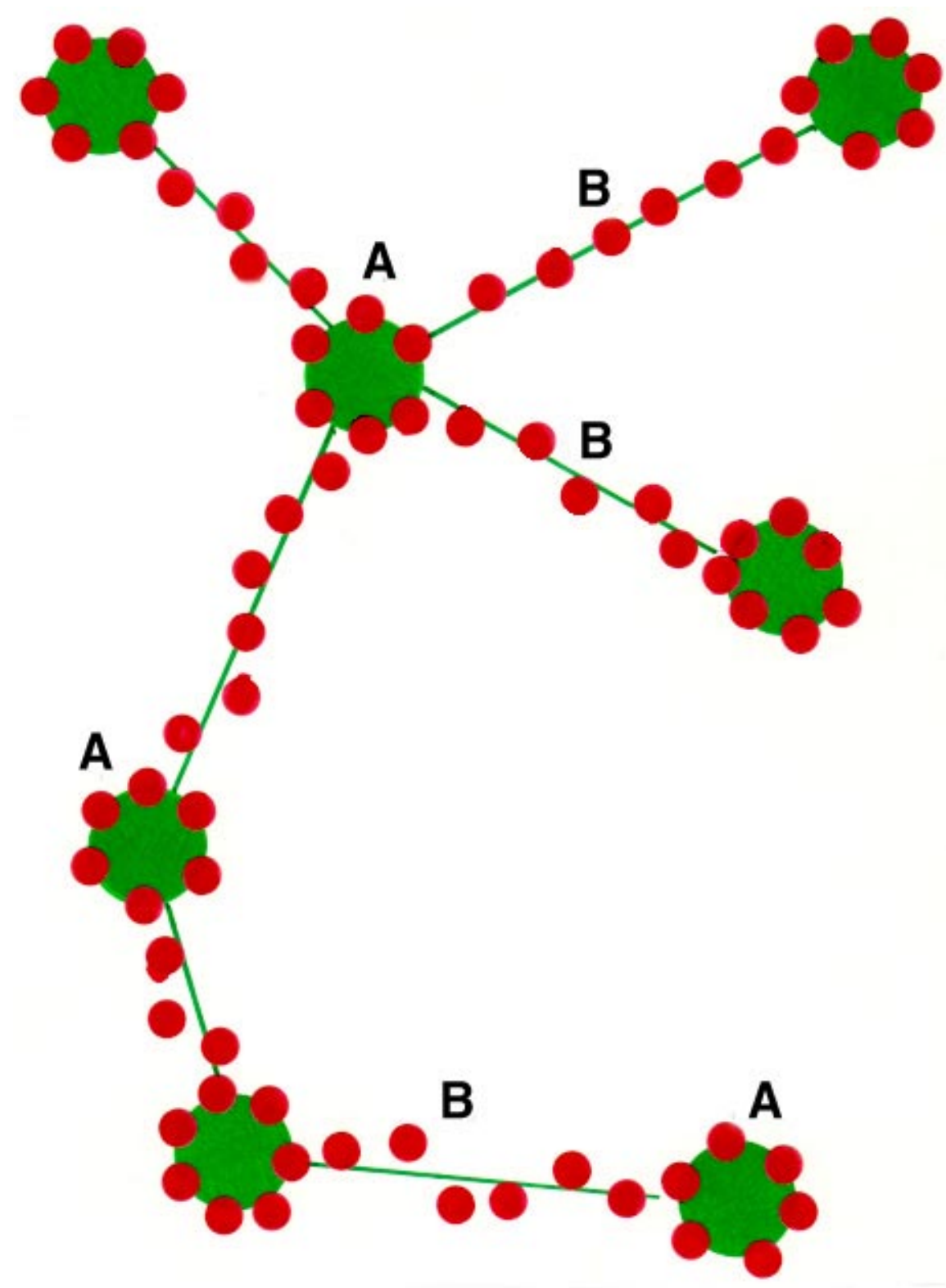

Fig. 14. Schematic representation (not to scale) of the relative positions of graftinoculated multiflora rose plants (red dots) in an augmented pasture. A, large green dots designate potential mite-overwintering sites; B, green lines designate disease alleys. 
this method of biocontrol has demonstrated that individual landowners can, within 2 to $4 \mathrm{~h}$, become proficient enough to successfully implement the method. Sixth, problems with product stability, as with certain other biocontrol agents, are not relevant.

\section{Outlook}

RRD has been shown to be effective for biocontrol of multiflora rose. Experimental clinics have provided managers of infested lands with necessary information to practice augmentation. Field laboratory demon-
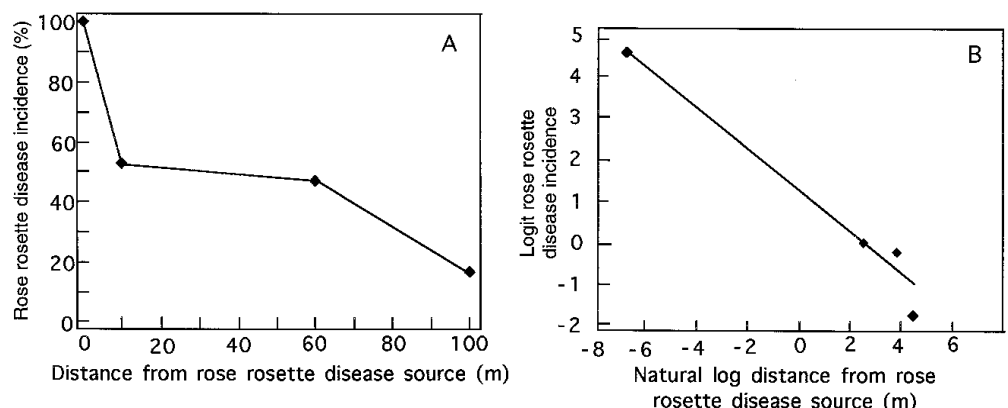

Fig. 15. (A) Disease gradient for rose rosette disease infection in multiflora rose as a function of the distance from rose rosette (augmented) sources of infection. Each point is the mean of the rose rosette disease gradients measured in the years 1993 to 1995. (B) Regression line and equation for the logit $Y$ - In distance $X$ disease gradient model applied to the data for (A). The slope of the regression line $(0.49)$ was significantly different from 0 and is a measure of the steepness of the gradient.

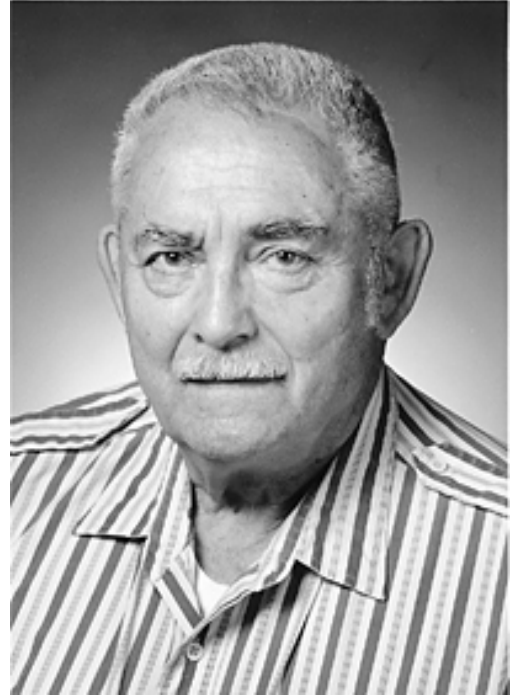

Abraham H. Epstein

Dr. Epstein is professor of plant pathology at lowa State University and former chairman of the department (1979 to 1990). He received an M.S. in horticulture and vegetable crops from Cornell University in 1952 and an M.S. in vegetable crop breeding and plant pathology from the University of Rhode Island in 1954. He completed a Ph.D. in plant pathology at lowa State University in 1969 and joined the Department of Botany and Plant Pathology as extension plant pathologist. Initially, he focused on remote sensing and early plant disease detection, and control of diseases of small grains. More recently, he has focused on the development of plant pathogens as agents for the biological control of weeds.

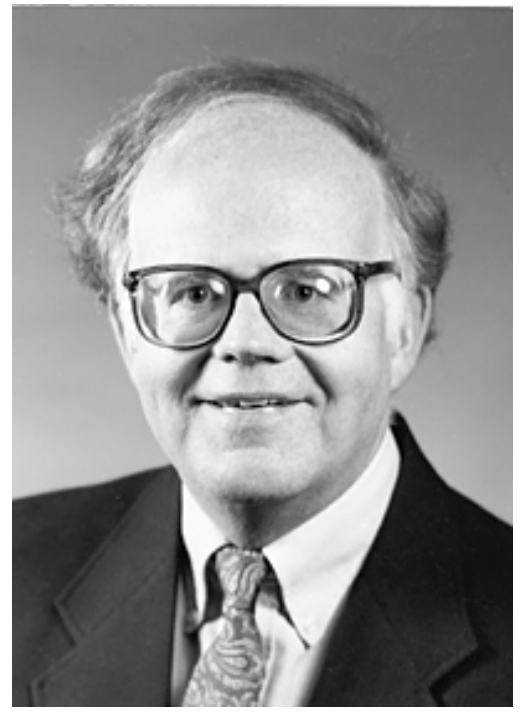

John H. Hill

Dr. Hill is professor of plant pathology at lowa State University. He received his B.A. in biology from Carleton College, Northfield, Minnesota, in 1963, and his M.S. in plant pathology in 1966 from the University of Minnesota. After completing his Ph.D. in plant pathology at the University of California-Davis in 1971, he joined the Plant Pathology Department at lowa State University. His work has focused on virus diseases of field crops with major emphasis on corn and soybeans. Most recently, his work has focused on soybean-soybean mosaic virus interactions. strations that provide "hands-on" experience have shown that land managers can utilize the grafting technique for augmentation that ultimately provides control. However, transmission by grafting, although effective, remains somewhat laborious and time-consuming. Effective manipulation of the mite vectors may provide an easier method for inoculating multiflora rose with RRD. Experiments are in progress to determine the most efficient method to achieve high levels of infection.

In addition, development of disease-specific probes will facilitate early detection of the causal agent and provide an efficient means for screening ornamental rose germ plasm for disease resistance. Efforts directed toward this objective are in progress.

\section{Acknowledgments}

We thank Thomas Bewick, University of Florida, for the gift of dodder seeds. We also thank the United States Army Corps of Engineers, the Iowa Agriculture and Home Economics Experiment Station, and the Iowa Department of Natural Resources for use of lands and assistance in establishing experimental plots. This research was supported in part by the supervisors of several southern Iowa counties, the Iowa Cattleman's Association, the Iowa Legislature, and the Leopold Center for Sustainable Agriculture. Journal Paper J-17695 of the Iowa Agriculture and Home Economics Experiment Station, Ames, Projects 2428 and 2984.

\section{Literature Cited}

1. Adams, A. N., and Thresh, J. M. 1987. Reversion of black currant. Pages 133-136 in: Virus Diseases of Small Fruits. R. H. Converse, ed. U.S. Dep. Agric. Handb. 631.

2. Ahn, K. K., Kim, K. S., Gergerich, R. C., Jensen, S. G., and Anderson, E. J. 1996 Comparative ultrastructure of double membrane-bound particles and inclusions associated with eriophyid mite-borne plant diseases of unknown etiology: A potentially new group of plant viruses. J. Submicrosc. Cytol. Pathol. 28:345-355.

3. Allington, W. B., Staples, R., and Viehmeyer, G. 1968. Transmission of rose rosette virus by the eriophyid mite Phyllocoptes fructiphylus. J. Econ. Entomol. 61:1132-1140.

4. Amrine, J. W., Jr., and Hindal, D. F. 1988 Rose rosette: A fatal disease of multiflora rose. W.Va. Univ. Agric. For. Exp. Stn. Circ. 147, Morgantown.

5. Amrine, J. W., Jr., Hindal, D. F., Stasny, T. A. Williams, R. L., and Coffman, C. C. 1988 Transmission of the rose rosette disease agent to Rosa multiflora by Phyllocoptes fructiphylus (Acari: Eriophyidae). Entomol. News 99:239-252.

6. Amrine, J. W., Jr., Hindal, D. F., Williams, R., Appel, J., Stasny, T., and Kassar, A. 1990 Rose rosette as a biocontrol of multiflora rose. Proc. South. Weed Sci. Soc. 43:316-319.

7. Brown, T. 1995. United States distribution of rose rosette disease. Pages 53-56 in: Proc. Int. Sympos. Rose Rosette Other Eriophyid MiteTransm. Plant Dis. Agents Uncertain Etiol. A. H. Epstein and J. H. Hill, eds.

8. Bryan, W. B., and Mills, T. A. 1988. Effect of frequency and method of defoliation and plant size on the survival of multiflora rose. Biol. Agric. Hortic. 5:209-214.

9. Connors, I. L. 1941. Twentieth Annual Report of The Canadian Plant Disease Survey, 1940. p. 98 . 
10. Crowe, F. J. 1983. Witches' broom of rose: A new outbreak in several central states. Plant Dis. 67:544-546.

11. Di, R., Hill, J. H., and Epstein, A. H. 1990. Double-stranded RNA associated with the rose rosette disease of multiflora rose. Plant Dis. 74:56-58

12. Doudrick, R. L. 1984. Etiological studies of rose rosette. M.S. thesis. University of Missouri, Columbia.

13. Doudrick, R. L., Enns, W. R., Brown, M. F., and Millikan, D. F. 1986.Characteristics and the role of the mite, Phyllocoptes fructiphylus (Acari: Eriophyidae) in the etiology of rose rosette. Entomol. News 97:163-168.

14. Epstein, A. H., and Hill, J. H. 1993. Rose rosette disease-pattern of spread in Iowa pastures. (Abstr.) International Bioherbicides Workshop II, McGill University. St. Anne-deBellevue, Quebec, CAN.

15. Epstein, A. H., and Hill, J. H. 1993. Rose rosette disease-Over wintering and increase of the vector as related to spread of the disease in Iowa. (Abstr.) Phytopathology 83:1339.

16. Epstein, A. H., and Hill, J. H. 1994. The biology of rose rosette disease: A mite-associated disease of uncertain etiology. J. Phytopathol. 143:353-360.

17. Epstein, A. H., and Hill, J. H. 1995. Field augmentation of rose rosette disease: Results and risk assessment. Pages 71-74 in: Proc. Int. Sympos. Rose Rosette Other Eriophyid MiteTransm. Plant Dis. Agents Uncertain Etiology. A. H. Epstein and J. H. Hill, eds.

18. Epstein, A. H., Hill, J. H., and Nutter, F. W. 1997. Augmentation of rose rosette disease for biocontrol of multiflora rose (Rosa multi- flora). Weed Sci. 45:172-178.

19. Epstein, A. H., Hill, J. H., and Obrycki, J. J. 1993. Rose rosette disease. Ia. State Univ. Ext. Publ. Pm 1532.

20. Hill, J. H., Epstein, A. H., Seibel, J. R., and Miller, W. A. 1995. Causal agent of rose rosette disease. Pages 57-60 in: Proc. Int. Sympos. Rose Rosette Other Eriophyid MiteTransm. Plant Dis. Agents Uncertain Etiology. A. H. Epstein and J. H. Hill, eds.

21. Hindal, D. F., and Wong, S. M. 1988. Potential biocontrol of multiflora rose (Rosa multiflora). Weed Technol. 2:122-131.

22. Jensen, S. G., Lane, L. C., and Seifers, D. L. 1996. A new disease of maize and wheat in the high plains. Plant Dis. 80:1387-1390.

23. Keifer, M. M. 1975. Eriophyoidea. Pages 327396 in: Mites Injurious to Economic Plants. L. R. Jeppson, M. M. Keiffer, and E. W. Baker, eds. University of California Press, Berkeley.

24. Kim, K. S., Ahn, K. K., and Gergerich, R. C. 1995. Double membrane-bound virus-like particles associated with rose rosette and some other diseases transmitted by eriophyid mites. Pages 34-41 in: Proc. Int. Sympos. Rose Rosette Other Eriophyid Mite-Transm. Plant Dis. Agents Uncertain Etiology. A. H. Epstein and J. H. Hill, eds.

25. Klimstra, W. D. 1956. Problems in the use of multiflora rose. Trans. Ill. Acad. Sci. 48:6672 .

26. Maramorosch, K., ed. 1992. Plant Diseases of Viral, Viroid, Mycoplasma and Uncertain Etiology. Westview Press, Boulder, CO.

27. Padgett, G. B., Nutter, F. W., Jr., Kuhn, C. W., and All, J. N. 1990. Quantification of disease resistance that reduces the rate of tobacco etch virus epidemics in bell pepper. Phytopathology 80:451-455.

28. Rheder, A. 1936. On the history of the introduction of woody plants into North America. Nat. Hortic. Mag. 15:245-257.

29. Schroeder, D. 1983. Biological control of weeds. Pages 41-78 in: Recent Advances in Weed Research. W. W. Fletcher, ed. Commonwealth Agricultural Bureaux, Slough, England.

30. Scott, R. F. 1965. Problems of multiflora rose spread and control. Trans. N. Am. Wildlife Nat. Reserv. Conf., 30th. 30:360-373.

31. Shvanderov, F. A. 1975. The role of phoresy in the migration of eriophyid mites (Eriophyoidea). Zool. Zh. 54:458-461. (Translation by J. W. Amrine, West Virginia University, Morgantown, WV, 1993).

32. Slykhuis, J. T. 1980. Mites. Pages 325-356 in: Vectors of Plant Pathogens. K. F. Harris and K. Maramorosch, eds. Academic Press, New York

33. Templeton, G. E., Tebeest, D. D., and Smith, R. J. 1979. Biological weed control with my coherbicides. Annu. Rev. Phytopathol. 17:301-310.

34. Thomas, E. A., and Scott, C. E. 1953. Rosette of rose. Phytopathology 43:218-219.

35. Underwood, J. F., Loux, M. M., Amrine, J. W., and Bryan, W. B. 1996. Multiflora Rose Control. Ohio State Univ. Ext. Bull. 857.

36. Wagnon, H. K. 1966. Report of a new or unusual plant pathogen: Witches' broom (rosette of rose). Calif. Dep. Agric. Plant Pathol. A-70-7.

37. Watson, A. K. 1981. Biological control of weeds. Proc. Spec. Sympos. Ecol. Agric. Biol. Cont. Annu. Meet. AAAS, Toronto. 